\title{
Primary Education Administration in Nigeria: Challenges and Strategies for Improvement
}

\author{
Agogbua Victor Ugochukwu ${ }^{1}$, Amobi Blessing Adaobi ${ }^{2}$, Anyaeji Adaora Vivian ${ }^{3}$ \\ ${ }^{I}$ Nnamdi Azikiwe University, Awka, Nigeria \\ ${ }^{2}$ Imo State University, Owerri, Nigeria \\ ${ }^{3}$ Nnamdi Azikiwe University, Awka, Nigeria
}

\begin{abstract}
The importance of education cannot be overemphasized following the total liberation it brought to man. Nigeria's education system is besieged by colossal problems ranging from inadequate funding, poor educational infrastructure, polluted learning environment, and recruitment of unqualified teaching personnel. This paper $x$-rayed challenges in the administration of primary education in Nigeria. The goals of primary education were highlighted. The paper identified major challenges confronting primary education administration in Nigeria including the wrong appointment of the head teacher, political instability, lack of supervision, etc. Going by the deplorable situation in primary education a reform is required to improve the performance of primary school administrators. Recommendations were made which suggested that the appointment of head teachers should be based on merit, not favoritism, internal and external supervision should also be encouraged to ensure rules and regulations are carried out as expected.
\end{abstract}

Keywords: Primary Education Administration, Primary School Challenges, School Administrative Challenges, Nigerian Primary Education

\section{INTRODUCTION}

$\mathrm{E}$ ducation is the single most significant element in the advancement of a nation. Its importance cannot be overemphasized as it plays a pivotal role in the supply of manpower needed for national development. Education as a development agent has made man useful, not only for himself but to his generation and beyond (Comfort et al 2013). The light of education to humanity has transformed man from ignorance to knowledge and happiness. Umoh (2006) averred that education specifically helps the individual to develop physically, mentally, morally, spiritually, and emotionally by providing suitable environment, teaching him new knowledge, attitudes and skills that will enable him to be useful to himself and his society. In the words of Raharjo (2018), education is vital requirement for man in order to undergo the process of social life. To promote national unity and peaceful coexistence that leads to national development, education of the citizenry starting from primary school level must be the government priority.

Primary education as stated in the National Policy on Education (2014) is the education given in institutions for pupils aged 6-12 years. The subsequent system of education is built upon primary-level education. Therefore, the key to the success or failure of the whole education system is dependent on what happens at this stage. In other words, it is the first formal foundation upon which all other formal levels of education are built. Primary education is the stage where a child's character is fashioned. The development of sound attitude, morals, and the ability to communicate effectively begins at this first formal stage of learning.

Mbayuav (2012) views primary education to be the recruitment ground for secondary education, and when the section is weak, it will affect the secondary education in the country. According to him, the current state and the products of primary education in the country is poor thereby making it difficult for secondary school administrators to effectively manage this set of students for higher productivity.

Nigeria's education system is besieged by colossal problems ranging from inadequate funding, poor educational infrastructure, polluted learning environment, and recruitment of unqualified teaching personnel. As the foundation to all other forms of education, primary education is expected to be reliable, strong, and reliable and have the capability of withstanding all forms of socio-cultural, ethnic and economic pressures. In the absence of necessary resources, efforts for the effective administration of schools will be thwarted.

Administration is the aspect of management that focuses on facilitating the realization of the stated objectives of a given organization through systematic management of problems and careful utilization of scarce resources. The researcher defines educational administration as the implementation and execution of plans, policies, and programmes to achieve educational objectives. Just like management, administration consists of such components as staffing, budgeting, planning, reporting, evaluation, organizing, and coordinating (Peretomode, 2004). The concept of school administration according to Glossary of Education (2012) is the task of planning, organizing, directing, and controlling human or material resources within a school. The challenges to effective administration of schools in Nigerian are not recent but it is as old as the introduction of formal education.

Glossary of Education (2012) pointed out that there is administrative team that is saddled with the task of planning, organizing, directing and controlling. This team of administrators found in primary schools includes the head 
teacher as the head of school administration, followed by the assistant head teacher, as the Head of Departments, and other departmental heads. Johnson (2012) agreed with Glossary of Education when he explained that school administration is the school's main governing body, and it plays a major part in decision making related to students, teachers and the school's overall status.

\section{THE GOALS OF PRIMARY EDUCATION IN NIGERIA}

Primary education is essentially the most important stage in the life of a child. This underscores the importance the government place on this level of education. The goals of primary education as listed in the National Policy on Education (NPE 2014:10) are as follows:

1. To inculcate permanent literacy and numeracy, and ability to communicate effectively;

2. To lay a sound basis for scientific and reflective thinking;

3. To give citizenship education as a basis for effective participation in and contribution to the life of the society;

4. To mold the character and develop sound attitude and morals in the child;

5. To develop in the child the ability to adapt to the child's changing environment;

6. To give the child opportunities for developing manipulative skills that will enable the child to function effectively in the society within the limits of the child's capacity;

7. To provide the child with basic tools for further educational advancement, including preparation for trades and crafts of the locality.

This goal launched in 1977 was reviewed in 1985 to include free primary education among others (Amaghionyeodiwe and Osinubi 2006). Nigerian government formulated the above goal in compliance with the United Nations Universal Declaration of Human Rights as it affects primary education.

\section{Challenges Confronting Primary Education in Nigeria}

A lot of factors militate against the progress of primary education in Nigeria. Some of these factors according to UNICEF are not different from those that had undermined economic and social advancement. These factors include but not limited to rapid population growth, staff indiscipline, overpopulation, and widespread poverty, improper distribution of education funds, top-down bureaucracies, and lack of learning facilities. Other problems facing the administration of primary education are $\mathrm{x}$-rayed below.

\section{Political Instability}

The progress of education has overtime suffered setbacks as a result of changes in political power. It is rather worrisome that new administration usually discontinues programmes put in place by the old administration thereby disorganizing the sector from growth. Lack of continuity has become the other of the day. Nigerian leaders also lack the political will and commitment to invest in education for the betterment of future generations.

\section{Problem of Leadership}

School administration officials are usually former teachers or principals who have worked hard to qualify for their position and have many years of experience. However, experience does not necessarily qualify one to be a good leader. Ozumba (2013) pinpointed that the problem of humanity has remained leadership despite the technological, scientific, economic development. Most school administrators do not adhere to policies. They do not have regular and open lines of communication with their subordinates or their superiors. Their leadership style has made the majority of them become less accessible leading to fewer face-to-face interactions which are important for both the teachers and the students. A disconnect can result in resentfulness on the part of the teachers who perceive a lack of concern and distorted priorities on the part of the leaders. When teachers become indignant, their performance suffers along with students' achievement.

\section{Appointment of Head Teachers}

Appointment or selection of head teachers in primary schools for some time now has been politicized. In most cases, it is influenced by the government in power and as such friends and relatives who may not be capable are appointed to the detriment of the effective administration of the school. This sort of political interference affects the achievement of the objectives of primary education since appointments are done not by merit but by favouritism. This, however, could lead to conflict in the system. Mapolisa and Tshabalala (2013) assert that favouritism by authorities as regards school administrator can bread conflict in the school system.

\section{Paucity of Fund}

Inadequate funding has been a major challenge in the smooth running of primary education in Nigeria. Budgetary allocation to education in year 2021 is $6.3 \%$ while UNESCO suggests $26 \%$ of the country's annual budget. No administration in recent times had got near to UNESCO's recommendation. Continued underfunding of education sector threatens the development, growth, and other administrative activities in the school. Shortage of finance in the sector is the result of unequipped libraries, overpopulation of classes, the dilapidation of facilities, high level of teachers' turnover, extortion, etc. Onanwa and Wisdom (2020) assert that the issue bothering on limited resources both at the local government level accounts for non-payment of salaries, dilapidating building and lack of infrastructure in primary schools. Approximately five percent of schools in Nigeria have no building (Adamu, 2007). He said that most of the buildings where available were either without roofs, inadequate, or in a terrible state. 


\section{Lack of Policy Implementation}

The National Policy on Education clearly listed out the objectives of primary education which includes among others, molding the character and developing sound attitude and morals in the child and giving the child opportunities for developing manipulative skills that will enable the child function effectively in the society within the limits of the child's capacity. Research finding by Dialoke et al (2017) showed that factors such as corruption, inadequate human and material resources, lack of continuity in government policies and clarity of purpose contributes to policy failure in Nigeria. Apart from receiving recommendation from stake holders in education, the implementation of the policy by relevant authorities has not been encouraging. The policy implementation, however, is yet to meet the expectation of the Nigerian government.

\section{Inadequate Supervision}

Edho (2009) asserts that lack of supervision and monitoring of schools are the major drawbacks in the education sector. The importance of external and internal supervision cannot be overemphasized. For primary education to remain relevant, attention must be given on the ways administrative duties are carried out as well as teaching and learning. Therefore, regular supervision is necessary to ensure the effective running the school. However, Edho (2009) blames poor response to supervision on inadequate vehicles for monitoring, poor funding for supervision, and insufficient number of qualified school supervisors. The success or failure of education in Nigeria is tied to the supervision of instruction.

\section{Connectivity and Resources Issues}

Public primary schools in remote Villages or rather economically backward schools face serious issues in keeping up with E-learning. Many students who were found sitting at home during the covid-19 pandemic were given no education as a result of lack of e-learning solutions. Village schools were completely short down without plans to keep the students mentally busy. This calls for government intervention otherwise students in such areas would get little or no basic education in the future.

\section{Shortage of Qualified and Committed Teachers}

Basically, teachers are taught to be change agents in the society. It has been observed that the majority of them do not pay attention to their work. They show lack of commitment as such new ways of teaching is not adopted. According to NEEDS (2014), the issue of shortage of professional teacher cut across all educational system in Nigeria. Many are mostly concerned about their monthly salary than imparting knowledge to the pupils. Guardian (2019) submitted that there is a shortage of 277,537 professional teachers in the public primary school in Nigeria. This, however, contributes to the reasons students lose interest in education at the early stage of their lives.

\section{Teachers' Out of Date Knowledge Base}

The $21^{\text {st }}$ century is an era of opportunities. To maximize these opportunities one's willpower must have to be activated. Teachers in primary level education lack this will to update themselves regarding modern theories and practices in education. They have maintained the old methods following their unwillingness (laziness) to take advantage of the new improved methods of teaching and learning. The resultant effect is that students are deprived of new knowledge as such give them grounds to lose interest in furthering their education as they cannot compete with their counterparts. Primary education is rapidly changing as a result of technological innovations and this require constant effort on the teacher to keep the pace (Dibal and Obaje, 2018)

\section{Lack of Co-Curricular Activities}

Activities here play a part in both the physical and mental development of the child. The researcher believes that "A sound body is a sound mind". Kariyana et al ( 2012) opined that co-curricular activities have a positive effect with students' academic success Public primary schools in Nigeria have large playground good for physical grooming, yet management lack dedication to engage pupils in all the required physical activities that would enhance their mental capacity.

\section{Strategies for Improvement}

For every problem, there must be a solution. Some of the strategies to improve the standard of primary education in the country includes but not limited to organizing workshops, seminars, conferences, role playing, and supplementary training programmes both for the teachers and head teachers. Other strategies for the elevation of the system are $\mathrm{x}$-rayed below.

\section{Continuous In-Service Teacher Programme}

If primary school teachers are to effectively and efficiently perform their functions, it becomes imperative for them to be retrained in new skills and modern methodology. The National Policy on Education (2014) states that no level of education can rise above the quality of its teachers. A continuous training programme in institutions of learning is necessary to enhance teachers' skills, knowledge, and experience. This is beneficial as it provides opportunities for increasing the number of trained and qualified teachers at all levels of education. Training teachers with current and up-todate materials and technology will improve the standard of primary education in the country.

\section{Improved Teachers' Welfare}

Poor teachers' salaries, bonuses, as well as irregularities in payments, were observed as factors affecting teachers' commitment to their job. Good housing, money, and a better working environment are motivating factors for teachers. Good welfare packages will serve as motivators to high productivity. Fair wages attract qualified and dedicated 
teachers and also will change the mind of young graduates towards the teaching profession. Annual review of salary will reduce incessant strike action in schools. Until the government treats teachers fairly the education output remains the same.

\section{Allocation of Sufficient Funds}

To lift the standard of our education from decadence, the government through the ministry of education must make available adequate funds for infrastructural development such as classrooms, electricity, equipped libraries, playground, pipe-borne water, etc. Adequate financing is vital in education as there are many compelling education needs like the purchase of equipment, instructional materials, in-service training programmes, seminars, workshops, and conferences for teachers (Nwiyi 2012). Finance is required in order for education system to actualize the millennium Development Goals. Allocation of funds to the education sector should at least meet up to UNESCO's minimum suggested standard. Education is the key to the development of a people but money is required to perform the needed magic.

\section{Political Stability}

Politics contributes to the setback education in Nigeria has suffered over time. To get things right there should be a law for continuity especially when it concerns education programmes in the country. This will compel the new administration to continue programme implementations from where the past administration stopped. Sincerity on the part of our politicians will help to lift education standards. Thus, lack of continuity will no longer be tolerated.

\section{CONCLUSION}

Going by the deplorable situation in primary education in Nigeria a reform is required to improve the performance of primary school administrators. The reformation needs to include proper funding, the appointment of qualified principals, provision of school facilities, marking out disciplinary measures against staff, and students' anti behaviours for the effective administration of primary schools in Nigeria.

\section{RECOMMENDATIONS}

Based on the issue at stake, the following recommendations are made:

1. The appointment of head teachers should be based on merit, not favoritism. Thus, politics should be discouraged for the smooth flow of administrative activities.

2. Teachers' welfare should be taken seriously for them to give their best in the administration of primary education in Nigeria.

3. There should be internal and external supervision of primary education to ensure rules and regulations are carried out as expected. This will help checkmate indiscipline among the teachers and the students.
4. Government through the Ministry of Education should see that the UNESCO $26 \%$ of national budget goes to education as this will enhance effective school administration.

\section{REFERENCES}

[1] Adamu, A.U. (2007). Financing Education Delivery in Nigeria: The Rhetoric and Realities. In Elizabeth Eke \& Raphael, O. Olarinoye (eds.) Politics of Nigerian Education. The Nigerian Academy of Education.

[2] Amaghionyeodiwe, L. A \& Osinubi, T. S. (2006). The Nigerian Systems and Return to Education. International Journal of Applied Econometrics and Quantitative Studies, 3 (1) 32-40.

[3] Comfort R. E, Usen F. M \& Ekpenyong E. E (2013) Primary Education as a Foundation for Qualitative Higher Education in Nigeria. Journal of Education and Learning, 2(2), 115-164.

[4] Dialoke, I., Ukeh, F., \& Maduagwuna, I. V.(2017). Policy Formulation and Implimentation in Nigeria: The Bane of Underdevelopment. International Journal of Capacity Building in Education and Management, 6(3), 22-27.

[5] Dibal, S. \& Obaje, M. (2018). Creativity and Functional Teacher Education in Nigeria Challenges and prospects in Comatose Economy. Journal of Resourcefulness and Distinction, 16(1), 6774.

[6] Edho, O. G. (2009). The Challenges Affecting the implementation of the Universal Basic Education (UPE) in Delta State, Nigeria. Journal of Social Sciences, 20 (3): 183-187.

[7] Eke, E. \& Olarinoye, R. D. (2006). Politics of Nigerian education: The Nigerian Academy of Education proceeding of $21^{\text {st }}$ Annual Congress of NAC held in Bauchi, 6-10 November.

[8] Federal Republic of Nigeria (2014). National Policy on Education. Lagos: NERDC.

[9] Guardian (My 09, 2019). Shortage of teachers, congestion, major challenges facing FCT school, http://guardian.ng/news/shortageof-teachers-congestion-major-challenges-facing-fct

[10] Glossary of Education (2012). School administration. 2006 2013. Education.com, Inc. www.education.com

[11] Johnson, S. (2013). Types of school administration. eHow 19992013 Demand Media, Inc.

[12] Kariyana, I., Maphosa, c. \& Mapuranga, B. (2012). The Influence of Learners' Participation in School Co-curricular Activities on Academic performance: Assessment of Educators' Perceptions. Journal of Social Science, 33(2), 137-149.

[13] Mapholisa, T., \& Tshabalala, T. (2013). An Investigation into the Causes of Conflict in Zimbabwe Schools: a Case Student of Khani SouthCircuit. Nova Journal of Humanities and Social Science, $1(1), 1-6$.

[14] Mbayuav, S.T (2012). The Challenges of Secondary Education in Nigeria: the way forward. Journal of pristine 4 (1): 104-112.

[15] NEEDS, (2014). Needs assessment in the Nigerian education sector. International organization for migration, Abuja, Nigeria.

[16] Nwiyi, G.U (2012). Attainment of Millennium Development Goals (MDGS) through Teacher Education programme in Nigeria. The Journal of Teacher Perspective 6 (13) 496-501.

[17] Odia, L.O., \& Omofonmwan, S. I. (2007). Educational system in Nigeria. Problems and prospects. Journal of Social Sciences, 14(1): 81-86.

[18] Onanwa, A. \& Wisdom, A. (2020). Improving Primary Education in Nigeria through Quality Control. European Journal of Education and Curriculum Studies, 3(2), 37-43.

[19] Ozumba, M. C. (2013). Bethrand Okafor and Martins Solomon Udom, "Plato and the Leadership Question: An Evaluation of Philosophy-King within the Nigerian Political Structure." The Nigerian Academic Forum, 20(1), 1-8.

[20] Peretomode, V.F. (2004). General Principles of School Administration. In V.F. Peretomode (ed.) Introduction to 
Educational Administration, Planning and Supervision. Lagos: Joja Press Limited.

[21] Raharjo, T. J (2018). Educational Foundation Semarang: PRES UNNES.
[22] Umoh, G. G. (2006). Path to Quantitative Education: A Standard Book for Students, Teachers and Educational Administrators. Uyo: Inela Ventures and Publishers. 